Kodifikasia : Jurnal Penelitian Islam, Vol 14, No. 01 (2020), 171-194

DOI : 10.21154/kodifikasia.v14i1.1952

ISSN : 1907-6371 (Cetak)

ISSN : 2527-9254 (Online)

\title{
MODEL PENERAPAN KONTRAK BISNIS SYARIAH DALAM MANAJEMEN RISIKO BMT UGT SIDOGIRI
}

Mohammad Ghozali*, Abdul Hafidz bin Zaid**, Badria Nur Lailina Ulfa***

\begin{abstract}
ABSTRAK:
KSPPS BMT UGT Sidogiri adalah salah satu BMT terbesar di Indonesia dengan banyak jaringan kantor cabang yang tersebar di Indonesia. BMT UGT Sidogiri memilikikinerja keuangan bagus dan terbaik dilihat dari perkembangannya beberapa tahun terakhir. Dengan pembiayaan yang semakin besar dan meningkat, maa pihak BMT haruslah siap untuk menghadapi risiko-risiko dalam pembiayaan dan operasionalnya. Maka BMT UGT Sidogiri memerlukan adanya penerapan manajemen yang baiksehingga mampu mengurangi risiko yang akan dihadapi dari setiap kegiatan yang dilakukan oleh pihak BMT. Penelitian ini merupakan kualitatif yang bersifat induktif. Pada penelitian ini maka permasalahan dibiarkan muncul untuk diinterpretasi. Data dikumpulkan dengan pengamatan, mencakup deskripsi dalam konteks mendetail yang disertai catatan hasil pengamatan, wawancara, serta hasil analisis dokumen dan catatan. Teknik analisis menggunakan deskriptif analitis. Dengan hasil penelitian bahwa BMT UGT Sidogiri dalam menerapkan kontrak bisnis syariah menggunakan prinsip 5C dan 1S yaitu: 1) Character, 2) Capacity, 3) Capital, 4) Collateral, 5 Condition of Economic dan 6) Sharia. Penerapan prinsip tersebut dalam manajemen risiko digunakan sesuai dengan Standart Operasional Prosedur yang berlaku, sehingga dapat menimialisir risiko yang terjadi dan juga dapat membantu mengembangkan usaha masyarakat sekitar.
\end{abstract}

Kata Kunci: Model Penerapan; Kontrak Bisnis Syariah; Manajemen Risiko

\footnotetext{
* Unversitas Darussalam Gontor, email : mohammadghozali@unda.gontor.ac.id

** Universitas Darussalam Gontor, email: abuafadh@unida.gontor.ac.id

*** Universitas Darussalam Gontor, email: badrianur36@gmail.com
} 


\begin{abstract}
:
KSPPS BMT UGT Sidogiri is one of the largest BMT in Indonesia with many branch offices in Indonesia. The BMT UGT Sidogiri has good financial performance and best viewed from its development in recent years. With the increasing of financing, the BMT must be ready to deal with the risks that involved in the financing and operations. Therefore, BMT UGT Sidogiri requires the implementation of good management to reduce the risk that will be faced by any activities undertaken by the BMT. This research uses an inductive qualitative method. This research let the problems appear to be treated for interpretation. The data are collected by observations, including the descriptions in a detailed context with the transcript of observations, interviews, documents and record analysis results. The analytical technique that used is descriptive analytic. With the results of study that BMT UGT Sidogiri in implementing of Sharia business contracts using the principles of 5C and 1S as follow: 1) Character, 2) Capacity, 3) Capital, 4) Collateral, 5 Condition of Economic and 6) Sharia. The implementation of these principles in the risk of management is used in accordance with the operational standards of the applicable procedures, so to be able to improve the risks that occur and also can help to develop the community's livelihood.
\end{abstract}

Keywords: Implementation Model; Sharia Business Contract; Risk Management

\title{
PENDAHULUAN
}

Koperasi Syariah merupakan salah satu bentuk dari Lembaga Keuangan Syariah (LKS) ${ }^{1}$ dalam bentuk non-Bank. Dimana dalam koperasi terdapat salah satu jenis lembaga keuangan yang sistem operasionalnya hampir sama dengan sistem operasional yang ada pada perbankan syariah, lembaga tersebut adalah Baitul Mal wa Tamwil.2Namun fakta yang ditemukan di lapangan bahwa implementasi produk perbankan belum semuanya sesuai dengan syariat Islam. Dalam penelitian Abbas Arfan Dkk menunjukkan 20\% produk perbankan di kota Malang diantaranya masih bertentangan dengan

${ }^{1}$ Merupakan implementasi pemahaman umat Islam terhadap prinsip-prinsip muamalah dalam hukum ekonomi Islam yang kemudian dipresentasikan dalam bentuk pranata ekonomi Islam sejenis LKS. Lihat, Syamsuir, "LembagaKeuangan Islam Non Bank," Jurnal Islamika 15(1) (2015): 90.

${ }^{2}$ Muhammad Sharif Chaudry, Sistem Ekonomi Islam: Prinsip Dasar, trans. oleh Suherman Rosyidi (Jakarta: Kencana Prenada Media Group, 2012), 32.

Kodifikasia: Jurnal Penelitian Islam, Volume, 14 No. 1 Tahun 2020 
fatwa DSN-MUI. ${ }^{3}$ Penelitian serupa juga dilakukan oleh Endro Wibowo ${ }^{4}$, dia menunjukkan bahwa BMT yang ditelitinya belum menerapkan prinsip syariah dalam prosesnya.

Dapat disimpulkan beberapa bentuk penyelewengan implementasi produk perbankan tersebut berkaitan dengan upaya pencegahan risiko yang mungkin terjadi pada lembaga perbankan.Fetria Eka Yudiana dalam penelitiannya menyatakan betapa pentingnya manajemen risiko untuk diterapkan karena setiap bisnis pasti mempunyai risiko baik berupa kerugian atau berupa kecurangan-kecurangan lainnya. ${ }^{5}$ Pengelolaan manajemen risiko ini dianggap sebagai salah satu elemen penting untuk memperkuat governance dan merupakan suatu kewajiban bagi perusahaan. ${ }^{6}$ Dalam penelitian Nurhayati menjelaskan, adanya penyelewengan mudah terjadi sejak pembiayaan itu telah disalurkan oleh BMT kepada anggota sampai dengan pembiayaan itu dibayar lunas oleh anggota.Oleh karena itu tugas BMT tidak hanya berhenti pada pemberian pembiayaan itu diberikan melainkan sampai dengan pembiayaan dibayar lunas oleh anggota. ${ }^{?}$

Berdasarkan penelitian sebelumnya perbedaan terletak pada objek penelitian manajemen risiko, lokasi penelitian dan fokus penelitian.Penulis memilih salah satu BMT, yakni KSPPS BMT UGT (Unit Gabungan Terpadu) Sidogiri merupakan salah satu BMT terbesar di Indonesia yang memiliki banyak jaringan kantor cabang yang tersebar di seluruh Indonesia. BMT UGT Sidogiri memiliki kinerja keuangan yang bagus dan terbaik dilihat dari perkembangannya beberapa tahun semakin meningkat pada pembiayaannya dan asset yang dimiliki. ${ }^{8}$ Dengan pembiayaan yang semakin besar dan meningkat, maka BMT UGT Sidogiri Cabang Larangan,

${ }^{3}$ Saifullah Abbas Arfan dan Fakhruddin, "Implementasi Prinsip Bagi Hasil dan Manajemen Risiko dalam Produk-Produk Pembiayaan Perbankan Syariah di Kota Malang," INFERENSI, Jurnal Penelitian Sosial Keagamaan 10(1) (2016).

${ }^{4}$ Endro Wibowo, "Manajemen Risiko Pembiayaan Murbahah di BMT Amanah Ummah," Jurnal Al-Tijarah 1(2) (2015).

${ }^{5}$ Fetria Eka Yudiana, "Manajemen Risiko dalam Prinsip Pembiayaan Mudharabah: Kajian Kontekstual Islam terhadap Risiko," Jurnal Muqtashid 1(2) (2010).

${ }^{6}$ Sulistyaningsih dan Barbara Gunawan, "Analisis Faktor-Faktor yang memengaruhi Risk Management Disclosure (Studi Empiris Pada Perusahaan Manufaktur yang Terdaftar di Bursa Efek Indonesia Tahun 2012-2014)," Analisis Faktor-Faktor yang memengaruhi Risk Management Disclosure (Studi Empiris Pada Perusahaan Manufaktur yang Terdaftar di Bursa Efek Indonesia Tahun 2012-2014), 2016.

7 Erni Nurhayati, "Pelaksanaan Pengawasan Murabahah Sebagai Upaya Untuk Memimalkan Pembiayaan Bermasalah” (UIN Malang, 2010), 19-20.

${ }^{8}$ Seperti fungsi intermediasi lembaga keuangan umumnya, BMT UGT Sidogiri menghimpun dana dari masyarakat dan menyelurkannya kembali kepada masyarakat yang membutuhkan dana dalam bentuk pembiayaaan.. KSPS BMT Sidogiri mencatat simpanan anggota tahun 2018 sebesar Rp. 392,7 Miliar dan Tabungan Rp. 1.474 Triliun. Adapun pembiayaan yang disalurkan mencapai Rp. 1,03 Triliun. Koperasi ini juga mempunyai 278 kantor cabang di 10 Provinsi. Lihat, Sejarah Berdirinya BMT UGT Sidogiri Pasuruan Jawa 
memerlukan adanya penerapan manajemen untuk meminimalisir risiko yang akan dihadapi dari setiap kegiatan yang dilakukan oleh pihak BMT. Hal inilah yang melatarbelakangi peneliti untuk meneliti lebih jauh tentang bagaimana model penerapan kontrak bisnis syariah dalam manajemen risiko di BMT UGT Sidogiri? Dan apakeunggulan manajemen risiko BMT UGT Sidogiri dalam penanggulangan terhadap pembiayaan kurang lancar?

Penelitian ini merupakan penelitian kualitatif dengan beberapa deskripsi digunakan untuk menemukan prinsip-prinsip dan penjelasan apa yang mengarah pada penyimpulan. Penelitian ini bersifat induktif, peneliti membiarkan permasalahan-permasalahan muncul dari data atau dibiarkan terbuka untuk interpretasi. Data dihimpun dengan pengamatan yang saksama, mencakup deskripsi dalam konteks yang mendetail disertai catatan hasil pengamatan, wawancara yang mendalam, serta hasil analisis dokumen dan catatan-catatan. Teknik analisis yang digunakan adalah deskriptif analitis bertujuan mendeskripsikan atau memberi gambaran terhadap suatu objek penelitian yang diteliti melalui data-data yang telah terkumpul dan membuat kesimpulan yang berlaku umum.

Terealisasinya penelitian ini bertujuan untuk pemanfaatan dalam Signifikansi Teoritis dan Signifikansi Praktisi. Adapun secara teoritis adalah untuk pengembangkan ilmu manajemen risiko khususnya pada lembaga keuangan koperasi simpan pinjam syariah dan pembiayaan terhadap anggota masyarakat.Untuk menambah wawasan terhadap lembaga keuangan syariah BMT Sidogiri dalam peningkatan sistem dan aplikasinya di masyarakat. Sebagai referensi dalam model penelitian yang serupa dan jika mungkin sebagai masukan atau solusi untuk mengatasi hambatan yang ditemukan baik sebagai praktisi maupun akademisi dalam peningkatan mutu pendidikan.Dalam Signifikansi Praktisipenelitian ini diharapkan dapat digunakan sebagai pedoman oleh para pihak dalam penerapan manajemen risiko untuk melaksanakan pembiayaan sesuai dengan konsep ekonomi syariah.Bagi pemerintah, dapat digunakan sebagai penelitian logis untuk mengembangkan penerapan manajemen risiko dalam pembiayaan yang terjadi di masyarakat dan anggota dengan menggunakan manajemen risiko berdasarkan pandangan ekonomi syariah.

\section{PEMBAHASAN}

\section{Produk Pembiayaan Akad Syariah di BMT Sidogiri}

Pembiayaan memiliki peranan yang sangat penting dalam lembaga keuangan atau Bank, karena pembiayaan mempunyai risiko yang sangat besar dalam

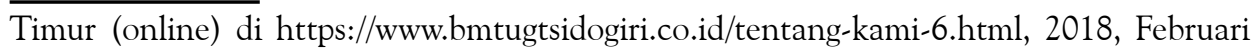
28

Kodifikasia: Jurnal Penelitian Islam, Volume, 14 No. 1 Tahun 2020 
kelangsungan hidup lembaga keuangan. ${ }^{9}$ Pembiayaan yang dikelola dengan baik akan memberikan pendapatan yang optimal, sebaliknya pembiayaan yang tidak dikelola dengan baik akan berakibatkan risiko pembiayaan yang besar dengan kemacetan yang terjadi. Demikian nama-nama produk pembiayaan di BMT Sidogiri sebagai berikut: ${ }^{10}$

1. Mudharabah (bagi hasil)adalah pembiayaan dengan modal keseluruhan oleh BMT, sedangkan anggota mengelola usaha dan manajemennya. Maka hasilnya dibagi sesuai dengan kesepakatan bersama berdasarkan ketentuan hasil yang disepakati.

2. Musyarakah (penyertaan)adalah pembiayaan yang diberikan kepada anggota sebagian dari modal keseluruhan.Dengan ini masing-masing pihak pekerja memiliki hak untuk turut serta membatalkan haknya dalam manajemen usaha tersebut.

3. Murabahah (jual beli)adalah pembiayaan terhadap jual beli dimana harga jual dan harga asal diketahui bersama ditambah keuntungan bagi BMT. Keuntungan adalah selisih antara harga jual dengan harga asal dengan kesepakatan bersama.

4. Bai' bitsamanai 'ajil (jual beli) adalah pembiayaan terhadap jual beli yang dilakukan secara angsur terhadap pembelian suatu harga.Jumlah kewajiban yang harus dibayar oleh pengguna jasa sebesar jumlah harga barang dan mark up yang telah disepakati oleh pengguna jasa.

5. Qard al-hasanadalah harta yang diberikan kepada orang lain yang mana dapat ditagih atau diminta kembali, dengan kata lain meminjamkan tanpa mengharapkan imbalan.

Demikian syarat dan ketentuan produk pembiayaan BMT UGT Sidogiri adalah:

a) Mengisi formulir pemohonan pembukaan tabungan.

b) Menjadi anggota atau mitra usaha.

c) Membuka rekening tabungan.

${ }^{9}$ Berbeda dengan zaman klasik bahwa akad syariah pada bank syariah mengalami banyak modifikasi dan penyesuaian sehingga dapat menghadapi risiko pembiayaan yang sama dengan bank konvensional. Lihat, Riana Afliha Eka Kurnia, "Manajemen Risiko Pembiayaan Untuk Mengantisipasi Kondisi Financial Distress Pada Bank Syariah," Journal of Islamic Economic Lariba 3(2) (2017): 51.

${ }^{10}$ Dokumen BMT UGT Sidogiri Standar Operasional dan Prosedur Tahun 2017. 
Tabel 1

Pembiayaan dan Risikonya

\begin{tabular}{|c|c|}
\hline Pembiayaan & Risiko \\
\hline Murabahah & $\begin{array}{l}\text { Pembiayaan dalam waktu yang terlalu lama ber-risiko tidak } \\
\text { dapat bersaing bagi hasil terhadap dana pihak ketiga }\end{array}$ \\
\hline Ijarah & $\begin{array}{l}\text { - Apabila barang yang disewakan adalah milik lembaga keuangan, } \\
\text { maka risikonya adalah asset ijarahtidak produktif. } \\
\text { - Apabila barang yang disewakan adalah bukan milik lembaga } \\
\text { keuangan, maka ber-risiko menimbulkan kerusakan pada ba- } \\
\text { rang akibat pemakaian diluar normal.Dengan ini maka, diper- } \\
\text { lukan adanya ganti rugi pada barang tersebut. } \\
\text { - Bila pembiayaan diberikan dalam bentuk jasa, maka ber-risiko } \\
\text { tidak performnya pemberi jasa.Demikian konven risiko adalah } \\
\text { tanggungjawab anggota karena pemberi jasa ini dipilih oleh ang- } \\
\text { gota sendiri. }\end{array}$ \\
\hline $\begin{array}{l}\text { Ijarah Muntahiya } \\
\text { Bit-Tamlik }\end{array}$ & $\begin{array}{l}\text { Apabila pendanaan menggunakan ballon payment, yakni } \\
\text { pembayaran dengan angsuran besar pada akhir periode,maka } \\
\text { risikonya adalah ketidakmampuan anggota dalam } \\
\text { membayarnya.Risiko ini dapat diatasi dengan perpanjangan } \\
\text { jangka waktu sewa. }\end{array}$ \\
\hline Salam dan Istisna' & $\begin{array}{l}\text { - Ber-risiko adanya kegagalan dalam pengambilan barang. } \\
\text { - Ber-risiko adanya jatuh pada harga barang. }\end{array}$ \\
\hline
\end{tabular}

Sumber: Adiwarman Karim, Bank Islam, Edisi Dua, Penerbit: PT Raja Grafindo Persada, Jakarta.

Beberapa Kebijakan Penggolongan Pembiayaan Bermasalah ${ }^{11}$

1. Prinsip penggolongan yang digunakan adalah:

a) Kehati-hatian dalam menyelamatkan dana milik masyarakat

b) Kemudahan terhadap perhitungan kualitas dana milik masyarakat

c) Perhatian terhadap hak-hak penyandang dana

2. Teknis finansial yang perlu diperhatikan:

a) Jenis angsuran

b) Jangka waktu

c) Masa penanganan dan penyelesaian

d) Jenis akad pembiayaan

3. Adanya tunggakan merupakan rentang waktu antaraangsuran yang disetorkan terakhir dengan tanggal jatuh tempo

4. Angsuran merupakan besar cicilan pokok dan profit (bagi hasil kerjasama, angsuran bagi hasil) atau profit yang harus dibayar setiap jatuh tempo angsuran.

5. Nilai transaksi jaminan adalah penilaian berdasarkan harga pasaran barang pada saat laporan dibuat.

${ }^{11}$ Dokumen Buku Panduan Rapat Anggota Tahunan KSPS BMT UGT SIDOGIRI INDONESIA Tahun Buku 2017.

Kodifikasia: Jurnal Penelitian Islam, Volume, 14 No. 1 Tahun 2020 
6. Tabel berikut merupakan penggolongan kolektabilitas:

Tabel 2

Penggolongan Kolektabilitas

\begin{tabular}{|c|c|c|}
\hline No & Skor & Predikat \\
\hline 1 & $81-100$ & SEHAT \\
\hline 2 & $66-<81$ & CUKUP SEHAT \\
\hline 3 & $51-<66$ & KURANG SEHAT \\
\hline 4 & $0-<51$ & TIDAK SEHAT \\
\hline
\end{tabular}

7. Setiap akhir bulan BMT harus mengeluarkan laporan keuangan kolektibilitas berdasarkan pada penggolongan di atas.

8. Berbagaicara dalam penanggulangan terhadap pembiayaan kurang lancar.

a. Memberikan teguran khusus yakni dengan memanggil anggota dengan baik secara kekeluargaan.

b. Mengunjungi atau menagih kerumah debitur (anggota)

c. Mengunjungi secara intensif hingga semua tunggakan dibayar lunas.

d. Debitur (anggota) tersebut diberikan penjelasan dan arahan berkaitan dengan perjanjian pembiayaan.

e. Selalu menjalin hubungan yang baik dengan debitur (anggota).

f. Adanya pengamalan ibadah dengan melakukan Istighotsah meminta pertolongan ketika keadaan sukar dan sulit.

g. Kepada seluruh kepala cabang BMT UGT Sidogiri melakukan ta'ziah atau ziarah ke makam-makam para syuhada' terdahulu, lebih mengamalkan ibadah, doa-doa, dan sholawat demi kemakmuran anggota, dimudahkan dalam urusan anggota, dilapangkan berkah dalam rezeki serta mampu menjadi umat yang bertaqwa.

9. Penanggulangan terhadap pembiayaan diragukan:

a. Mengunjungi rumah debitur atau anggota dan melakukan musyawarah berkaitan dengan solusi penyelesaian pada pembiayaan dan menunjukkan fotocopy akad pembiayaan.

b. Memberikan waktu untuk segera menyelesaikan pembiayaan tersebut, maksimal diberi adalah satu bulan.

c. Jika debitur atau anggota sudah tidak dapat menyelesaikan pembiayaan tersebut, maka BMT melakukan proses "Prosedur Kebijakan Jadwal Ulang (Rescheduling)".

d. Jika sudah diberikan keringanan tersebut namun tetap saja tidak dapat menyelesaikan pembiayaannya, maka BMT melakukan 'Prosedur Kebijakan Pengambilan Hak Tanggungan”. 
10.Penanggulangan terhadap pembiayaan macet: ${ }^{12}$

a. mengunjungi rumah anggota, menunjukkan fotocopy akad pembiayaan dan memberikan waktu pelunasan maksimal adalah satu bulan.

b. jika anggota sudah tidak dapat menyelesaikan pembiayaan tersebut, maka BMT melakukan proses "Prosedur Kebijakan Jadwal Ulang (Rescheduling)".

c. Apabila sudah diberikan keringanan tersebut namun tetap tidak dapat menyelesaikan pembiayaannya, maka BMT melakukan 'Prosedur Kebijakan Pengambilan Hak Tanggungan".

11.BMT UGT Sidogiri harus senantiasa melakukan tindakan penyelamatan dan melakukan evaluasi terhadap hasil yang diperoleh.

12.Penghapusan atas pembiayaan-pembiayaan dari CPP yang dicadangkan harus melalui kajian dan alasan-alasan yang jelas dan dibuat berita acara.

13.Penghapusan atas pembiayaan, dilakukan oleh komite yang terdiri atas Manager Marketing, Manager Operasional, Kepala Cabang, Kasir atau Administrasi, Legal Remedial atau Personalia, Direktur dan Ketua Pengurus atau yang mewakili Pengurus.

\section{Manajemen Risiko Pembiayaan BMT UGT Sidogiri Periode 2014. 2018}

Manajemen risiko merupakan salah satu metode atau pendekatan ilmiah yang menangani risiko murni dengan cara mendesain dan melaksanakan prosedur untuk memperkecil kemungkinan terjadinya kerugian yang akan akan berdampak terhadap masalah keuangan dalam pengelolannya. ${ }^{13}$ Manajemen sebagai suatu seni ${ }^{14}$ untuk mencapai hasil yang sebesar-besarnya dengan usaha yang maksimal.Demikian adalah demi mencapai kesejahteraan maksimal baik bagi pimpinan, karyawan danmasyarakat.

Risiko merupakan bagian yang melekatdalam kehidupan, sebagaimana adanya kehidupan dan kematian.Risiko bisa saja tidak terjadi, namun ada kemungkinanuntuk terjadi, dengan kata lain bahwa risiko bersifat tidakpasti.Jadi pengertian risiko yaitu akibat yang dihadapi atau diterima berhubungan dengan ketidakpastian, dapat berupa kemungkinan rugi

${ }^{12}$ Dokumen BMT UGT Sidogiri Standar Operasional dan Prosedur Tahun 2017.

${ }^{13}$ Hajar, "The Financing Risk Management Analysis of Natural Uncertainty Contracts (NUC): Study of PT. Bank Syariah Mandiri Area Office of Malang," Journal Anil Islam 10(1) (2017): 126.

${ }^{14}$ Dapat diartikan sebagai upaya pencapaian terhadap tujuan dengan pendekatan, menjelaskan fenomena-fenomena, gejala-gejala manajemen juga mentransformasikan serta mengidentifikasi proses suatu manajemen berdasar pada kaidah ilmiah. Lihat, Samuel Batlajery, "Penerapan Fungsi-Fungsi Manajemen Pada Aparatur Pemerintahan Kampung Tambat Kabupaten Merauke," Jurnal Ilmu Ekonomi Eु Sosial 7(2) (2016): 138.

Kodifikasia: Jurnal Penelitian Islam, Volume, 14 No. 1 Tahun 2020 
dan probabilitas hasil yang berbeda dari yang diinginkan.Risiko berkaitan dengan kemungkinan akanterjadinya akibat kerugian yang tidak diinginkan atau tidak terduga. ${ }^{15}$

Dalam pengelolaannya, manajemen risiko dalam pembiayaan tidak dapat dipisahkan dari risikolainyang sangat bekaitan dengan operasional penerapan lembaga keuangan, namun risiko ini dapat dikelola dan dikendalikan. ${ }^{16}$ Permasalahannya adalah bagaimana suatu perusahaan dapat mengelola agar investasi atau bisnis dalam pembiayaan memiliki risiko seminimal mungkin. ${ }^{17}$ Tentu Rrisiko pembiayaan tersebut bisa diminimalisir yaknidengan pengelolaan manajemen risiko dengan baik dan tepat sesuai syariah.

Risiko pembiayaan atau kredit merupakan risiko paling besar dampak dan potensi terjadinya akibat dari kelalaian atau kegagalan tagihan pembayaran nasabah dalam peminjaman.Oleh karena itu, risiko pembiayaan pada Perbankan memiliki perhatian lebih di Antara jenis risiko lainnya. ${ }^{18}$ Dalam hal ini, BMT UGT Sidogiri mengutamakan pelayanan yang menarik bagi anggota dalam menabung, meningkatkan jumlah pembiayaan yang dibutuhkan anggota demi kemajuan usahanya juga meningkatkan jumlah danabagi pihak ketiga (adanya tolong menolong) yang dikelola untuk kegiatan pembiayaan. ${ }^{19}$

Umumnya risiko terkait aktivitas fungsional bank syariah dapat diklasifikasikan menjadi tiga jenis sebagai berikut: 1) Risiko pembiayaan, 2) Risiko pasar, terdiri dari forex risk, interst risk, liquidity risk dan price risk, 3) Risiko operasional, terdiri dari transactional risk, compliance risk, strategic risk, reputation risk dan legal risk. ${ }^{20}$ Untuk mengatisipasi adanya risiko tersebut, hal yang harus dilakukan BMT adalah tetap memberikan pelayanan yang baik kepada anggota demi menghasilkan jumlah dana yang maksimal. Pelayanan yang diberikan mampu menarik anggota dalam

${ }^{15}$ I W. Wedana Yasa dan Dkk, "Manajemen Risiko Operasional Dan Pemeliharaan Tempat Pembuanagan Akhir (TPA Regional Bangli Di Kabupaten Bangli," Jurnal Spektran 1(2) (2013): 32.

${ }^{16}$ Ahmad Mukhlisin dan Aan Suhendri, "Analisis Manajemen Risiko (Kajian Kritis Terhadap Perbankan Syariah di Era Kontemporer)," An-Nisbah: Jurnal Ekonomi Syariah 5(1) (2018): 259.

${ }^{17}$ Juried, "Manajemen Risiko Bank Islam (Penanganan Pembiayaan Bermasalah Dalam Produk Pembiayaan Pada PT. Bank Muamalat Cabang Pembantu Penyambungan)," Journal Analytica Islamica 5(1) (2012): 89.

${ }^{18}$ Sumar'in, Konsep Kelembagaan Bank Syariah (Yogyakarta: Graha Ilmu, n.d.), 110.

${ }^{19}$ Bustami, "Manajemen Risiko Pembiayaan Dardhul Hasan Menurut Perspektif Ekonomi Islam (Studi pada Baitul Qiradh Amanah Banda Aceh)," Jurnal Share 3(1) (2014): 83.

${ }^{20}$ Adiwarman A. Karim, Bank Islam: Analisis Fiqih dan Keuangan (Jakarta: Raja Grafindo Pustaka, 2014), 58. 
menabung dan pembiayaan yang dibutuhkan.berikutpenjelasan Bapak Zainuddin Abbas bahwa:

"Risiko pada awalnya selalu ada setiap kegiatan usaha bisnis, khusunya dalam lembaga keuangan syariah seperti BMT.Risiko pembiayaan yang dihadapi BMT pasti kami terima dan tidak lepas dari risiko-risiko pembiayaan anggota dalam kegiatan penerapan operasional kegiatan BMT.Sebagai contoh adalah risiko pasar, untuk meminimalisir adanya risiko tersebut, maka kami sebagai lembaga syariah memiliki beberapa strategi yang kami lakukan, diantaranya adalah dengan meningkatkan kepuasan anggota dalam menabung dan peminjaman.Sebenarnya tidak ada saingan dengan lembaga keuangan lainnya kami tidak mempersalahkan itu. Namun kami lebih mengutamakan pelayanan kepada para anggota untuk menarik minat anggota dalam menabung dan meningkatkan jumlah pihak dana ketiga yang disalurkan untuk kegiatan pembiayaan,"21

Demikian data peningkatan jumlah pembiayaan di BMT Sidogiri untuk setiap tahun: ${ }^{22}$

Tabel 3

Data Pembiayaan Anggota Tahun 2011-2018

\begin{tabular}{|c|c|c|c|c|}
\hline \multicolumn{5}{|c|}{ Data Nominal Pembiayaan Anggota Tahun 2011-2018 } \\
\hline No & 2011 & 2012 & 2013 & 2014 \\
\hline 1 & 350.350 .000 & 1.143 .331 .000 & 2.419 .606 .000 & 3.327 .338 .000 \\
\hline 2 & 823.876 .000 & 2.178 .803 .000 & 2.612 .240 .000 & 3.365 .725 .000 \\
\hline & 2015 & 2016 & 2017 & 2018 \\
\hline 1 & 3.925 .103 .000 & 4.434 .381 .000 & 2.765 .070 .000 & 1.420 .201 .000 \\
\hline 2 & 4.204 .165 .000 & 4.288 .535 .000 & 2.358 .301 .000 & 1.883 .933 .000 \\
\hline
\end{tabular}

BMT UGT Sidogiri dalam hal pembiayaan, memiliki cadangan danademipemenuhan terhadap kebutuhan jangka pendeknya. Adapun risiko dalam jangka pendek tersebut diantaranya adalah memenuhi tarikandana sewaktu-waktu oleh deposan dan risiko likuiditas dalam memenuhi kewajiban lembaga yang telah jatuh tempo. Dengan adanya kebutuhan mendadak makajika dana cadangantidak cukup untuk memenuhi kebutuhan tersebut, pihak BMT akan meminjam dana kepada kantor pusat atau cabang lain dalam satu kabupaten. Adapun yang diungkapkan oleh Bapak Zainuddin:

"Kami dari lembaga UGT sendiri lebih mengutamakan adanya kebutuhan dari anggota, baik anggota penabung ataupun anggota pembiayaan. Dalam memenuhi kebutuhan anggota penabung, kami selalu menyediakan dana untuk memenuhi penarikan uang anggota yang dilakukan sewaktu-waktu. Apabila memang adanya

${ }^{21}$ Wawancara dengan Bapak Zainuddin Abbas (Kepala Bagian Pembiayaan Kantor Cabang Larangan), 22 Januari 2019.

${ }^{22}$ Ibid

Kodifikasia: Jurnal Penelitian Islam, Volume, 14 No. 1 Tahun 2020 
kebutuhan dana yang mendadak dan memungkinkan peminjamanan dana secara mendadak, kami akan meminjam dana dari kantor cabang pembantu yang tersebar di kecamatan porong dan kabupaten Sidoarjo. Apabila adanya dana pinjaman tersebut tidak bisa memenuhi kebutuhan jangka pendek untuk anggota pembiayaan, maka langkah selanjutnya yang akan dilakukan adalah meminjam dana dari kantor pusat Pasuruan." 23

Dalam hal pembiayaan maka manajemen risiko pembiayaan merupakan salah satu proses yang sangat penting untuk diperhatikan. Dengan adanya manajemen risiko dapatdiketahui adanya permasalahan yang akan dihadapi di masa mendatang ${ }^{24}$ serta cara pengendaliannya dalam meminimalisir risiko pada pembiayaan. ${ }^{25}$ Manajemen risiko pembiayaan ini diawali dengan proses identifikasi, meliputi identifikasi kemampuan anggota untuk mengembalikan pembiayaan yang diberikan lembaga beserta jaminan yang memadai. Seperti yang telah dijelaskan oleh bapak Abbas Zainuddin:

Dalam proses pembiayaan kepada anggota, adanya Identifikasi yang dilakukan untuk mengetahui akan adanya risiko yang dihadapi pada pembiayaan, dengan mengideintifkasi usaha yang dijalankan dari calon anggota. Dengan memperhatikan usaha yang dimiliki anggota adalah hal terpenting dalam demi kelancaran angsuran oleh calon anggota.Identifikasi usaha dapat dianalisis dengan melihat pada laporan keuangan sebelumnya, guna melihat perkembangan usahanya tersebut. Selain itu proses identifikasi risiko dapatdilihat dari karakter calon anggota, hal ini juga harus diperhatikan dalam sifat masing-masing anggota, mengantisipasi adanya kasus misalorang tersebut dalam usahanya lancar, namun tidak melakukan angsuran pembayaran tepat pada waktunya. Demikian menunjukkan bahwa demi kelancaran angsuran anggota penilaian karakter sangatlah penting.Dengan melakukan analisis makatentu sangat membantu dalam penilaian survey anggota secara langsung dilapangan dan mengetahui risiko yang akan dihadapi kemudian hari."26

${ }^{23}$ Wawancara dengan Bapak Zainuddin Abbas (Kepala Bagian Pembiayaan Kantor Cabang Larangan), 22 Januari 2019.

${ }^{24}$ Potensi tersebut berpeluang terjadi karena ketiakpastian tentang situasidan kondisi di masa yang akan datang. Lihat, Bayu Wijayantini, "Model Pendekatan Manajemen Risiko," Jurnal Jeam 11(2) (2012): 58.

${ }^{25}$ Pengurangan risiko dalam kegiatan ekonomi dan bisnis dapat dilakukan dengan penerapan manajemen Islami yaitu menggunakan tiga level pendekatan berbasis ekonomi syariah diantaranya sebagai pondasi adalah Tauhid, Adil, Nubuwah, Khilafah dan Ma'ad, sebagai tiang adalah multiple ownership, freedom to act, social justice, sebagai atap adalah akhlakul kharimah. Lihat, Asep Dadan Sugana, "Mengurangi Tingkat Risiko Dengan Manajemen Islami," Islamiconomic Jurnal Ekonomi Islam 6(2) (2015): 10.

${ }^{26}$ Wawancara dengan Bapak Zainuddin Abbas (Kepala Bagian Pembiayaan Kantor Cabang Larangan), 26 Agustus 2018. 
Adanya beberapa karakter menjadikan hal terpenting dalam aspek pembiayaan pada anggota. ${ }^{27}$ Selain itu, bahwa pihak lembaga BMT juga melakukan analisis terhadap barang yang menjadi agunan. Identifikasi dalam proses penilaian adanya hambatan usaha yang dijalankan anggota sangat diperhatikan, demi mengetahui perkembangan usaha dan kelancaran operasional usaha anggota. Seperti yang diungkapkan oleh Bapak Zainuddin Abbas:

"Pembiayaan anggota haruslah diperhatikan, baik tempat dan usaha yang dilakukan anggota, serta adanya suatujaminan menjadi faktor penting pada syarat pembiayaan. Jaminan yang diberikan oleh calon anggota dalam pembiayaan, menjadikan suatu penilaian bagi kami untuk mengetahio sejauh mana keseriusan anggota untuk mengembalikan dana yang dipinjamkan, jika dana yang dipinjam besar nominalnya, maka agunan yang diberikan bernilai pada notaris. Dengan adanya agunan maka risiko yang ditimbulkan dalam pembiayaan dapat terminimalisir." ${ }^{28}$

Dalam manajemen risiko pembiayaan, proses selanjutnya pada pengukuran risiko. ${ }^{29}$ Pengukuran risiko memiliki tujuan terhadap besar kecilnya risiko yang akan dihadapi pada anggota dan lembaga. Diantara produk pembiayaan BMT UGT Sidogiri yang memiliki risiko besar adalah UGT Kendaraan Bermotor Barokah (KBB) dan produk pembiayaan Modal Usaha Barokah (MUB) atau Mudharabah.Beriku penjelasan bapak Zainuddin Abbas bahwa:

"Pada dasarnya seluruh pembiayaan pasti tidak jauh adanya risiko, baik itu bersiko rendah ataupun tinggi. Dalam pembiayaan yang dimiliki BMT, produk yang dominan paling tinggi risiko adalah produk UGT Kendaraan Bermotor Barokah (KBB) dan produk pembiayaan Modal Uaha Barokah (MUB) atau Mudharabah. Kedua produk tersebutmempunyai risiko tinggi.Adanya pengukuran pada risiko ini, didapatkan pada evaluasi bulanan, transparasi akuntabilitas, serta laporan kolektibilitas harian." 30

${ }^{27}$ Seperti yang dikatakan oleh analis pembiayaan produktif bahwa jaminan itu tidak wajib namun yang paling utama adalah karakterya.Bahkan terdapat suatu kasus dalam beberapa keadaan Bank BRI Syariah tidak mewajibkan adanya jaminan, jika nasabah memiliki karakter yang baik. Lihat, Asmirawati dan Sumarlin, "Perilaku Moral Hazard Nasabah Pada Pembiayaan Berbasis Bagi Hasil Pada Perbankan Syariah," Jurnal Laa Maysir 5(1) (2018): 138.

${ }^{28}$ Wawancara dengan Bapak Zainuddin Abbas (Kepala Bagian Pembiayaan Kantor Cabang Larangan), 22 Januari 2019.

${ }^{29}$ Pengukuran Risiko dilakukan dengan identifikasi nilai menggunakan standar pengukuran risiko.Hasil identifikasi kemungkinan terjadi risiko dan dampaknya dikonversi kedalam skor, kemudian hasilnya dikelompokkan ke dalam klasifikasi tingkatan risiko. Lihat, Riska Nisrina, Fathur Rahman, dan Dkk, "Pengukuran Risiko Pembiayaan Pada BMT Di Kota Tasikmalaya," Jurnal Riset Akuntansi dan Keuangan 6(3) (2018): 386.

${ }^{30}$ Wawancara dengan Bapak Zainuddin Abbas (Kepala Bagian Pembiayaan Kantor Cabang Larangan), 22 Januari 2019. 
Setelah melakukan adanya pengukuran selanjutnya pihak BMT memberikan strategi supaya risiko bisa diminimalisir.Maka langkah pertama yang diambil adalah penetapan jumlah DP minimal yang harus dibayarkan oleh calon anggota ketika mengajukan pembiayaan KBB dan jumlah maksimal pembiayaan yang dikeluarkan oleh calon anggota yang mengajukan produk MUB.Berikut penjelasanbapak Abbas bahwa:

"Pembiayaan modal usaha barokah, memiliki risiko yang rendah, karena kondisi perekonomian saat ini sangat tidak memungkinkan sekali mendukung kelancaran usaha calon anggota.Baik dalam usaha sekor perdagangan, pertanian dan usaha lainnya.Sedangkan Mudharabah dan Kendaraan Bermotor Barokah, untuk didahulukan membayar DP minim, karena hal ini sering dihadapi adanya risiko kredit macet.Jadi dalam produk KBB harus lebih teliti dalam menilai kelayakan pada anggota pembiayaan, baik dari biaya DP dan jaminan.Dengan ini makapembeli motor mampu menggadaikan motornya atau menjual motornya sebelum angsuran berakhir.Makabesar DP minimal adalah 25\% dari harga motor, agar risiko yang dihadapi dapat diminimalisir.Sedangkan untuk modal usaha barokah maksimal $60 \%$ dari harga jual jaminan pada anggota." ${ }^{31}$

Selanjutnyaadalah pengawasan risiko pembiayaan.Kepala bagian legal dan remedial BMT UGT Sidogiri selalu mengontrol terhadap kedisiplinan pembayaran dari anggota pembiayaan. ${ }^{32}$ Kepala bagian simpan pinjam pembiayaan bekerja sama dengan Account Office (AOP) dalam pengawasan terhadap perkembangan usaha dan kedisplinan anggota melakukan pembayaran angsuran. Seperti dijelaskan oleh bapak Abbas:

"Dalam hal pengawasan risiko, saya sebagai kepala simpan pinjam pembiayaan bekerja sama dengan AOP (Account Officer Pembiayaan) mengonrolperkembangan usaha dari anggota setiap hari, memastikan bahwa usaha yang dijalankan terus produktif, manfaat, dan dapat mamahami sejak awal masalah yang dihadapi oleh anggota pembiayaan. AOP menhubungi anggota yang bermasalah, agar lebih disiplin dalam pembayaran angsuran dan memberi peringatan atau dakwah dengan kekeluargaan pada anggota." 33

Sebagai contoh kasus dalam pengendalian risiko, BMT UGT Sidogiri melakukan pembinaan secara kekeluargaan: Penjual sotomengambil

${ }^{31}$ Wawancara dengan Bapak Zainuddin Abbas (Kepala Bagian Pembiayaan Kantor Cabang Larangan), 22 Januari 2019.

${ }^{32}$ Untuk menghadapi kemungkinan risiko kecurangan atau kelalaian nasabah dapat juga dilakukan dengan pengawasan secara aktif dan melakukan pemeriksaan secara langsung terhadap operasional bisnis, maupun berkas-berkas nasabah. Lihat, Kurnia, "Manajemen Risiko Pembiayaan Untuk Mengantisipasi Kondisi Financial Distress Pada Bank Syariah," 51.

${ }^{33}$ Wawancara dengan Bapak Zainuddin Abbas (Kepala Bagian Pembiayaan Kantor Cabang Larangan), 27 Januari 2019. 
keuntungan setiap bulandengan ketentuan akad musyarakah. Dalam pembagian hasil, BMT tidak ingin memberatkan adanya bagi hasil persen pada setiap bulannyakarena kemungkinanterjadi risiko kerugian yang akan terjadi.Jika salah satu anggota berhenti dalam angsurannya, maka khususnya account officer pembiayaan menghubungianggota untuk disampaikan pesan, didatangi dan terakhir diberikan surat peringatan. Demikian dilakukan untuk mengetahui sebab pembiayaan yang bermasalah pada anggota. ${ }^{34}$

Dalam proses manajemen risiko pembiayaan yang paling akhir adalah pengendalian. ${ }^{35}$ Pengendalian ini dilakukan terhadap risiko dengancaramenganalisa, melihat sebabadanya risiko serta menentukan langkah apa yang akan dilakukan. Langkah awal oleh Account officer manajerial dari BMT UGT Sidogiri yaknidenganbersilaturahmi ke rumah anggota yang mengalami masalah pada pembiayaan, selain itu adanya panggilan dengan teguran di berikan nasihat dan dakwah kepentingan dalam melunasi kewajibannya.Namun apabila langkah tersebut belum dapat mengendalikan risiko tersebut, maka pihak BMT memberikan surat peringatan.

"Lembaga keuangan Islam dengan memiliki visi misi dalam mensejahterakan anggota, maka dalam hal ini pihak BMT kami lebih mengutamakan adanya kekeluargaan kepada anggota. Membantu dalam mengembangkan usahanya dan kesejahteraan ummat, sehingga langkah awal yang akan digunakan dengan mendatangi atau silaturahmi kerumah anggota pembiayaan yang bersangkutan, menanyakan sebab terjadinya ketidakmampuan bayar angsuran tersebut. Maka dari sini akan mampu mengetahui apakah benar-benar tidak mampu membayar, atau tidak ingin melunasi angsuran. Dari segi financial ada yang mampu namun tidak mau mengangsur bayaran, tentunya adanya tindakan khusus agar anggota bisa memenuhi kewajibannya." 36

Dalam pengendalian manajemen risiko, BMT melakukan reschedule terhadap anggota yang masih bisa dibina dan diajak untuk melakukan pembayaran kembali. Seperti penjelasan bapak Abbas sbagai berikut:

"Iika anggota tidak mampu membayar dengan analisis masih bisa dibina, maka kami pihak BMT akan melakukan reschedule. Misalnya usaha yang dijalankan tidak

${ }^{34}$ Wawancara dengan Bapak Zainuddin Abbas (Kepala Bagian Pembiayaan Kantor Cabang Larangan), 27 Januari 2019.

${ }^{35}$ Pengendalian risiko adalah alat bantu bagi pengusaha dalam proses pengambilan suatu keputusan untuk mengurangi atau menghindari risiko yang dihadapinya. Lihat, Eka Pariyanti, "Analisis Pengendalian Resiko Pada Usaha Keripik Singkong," Jurnal Manajemen Magister 3(1) (2017): 34.

${ }^{36}$ Wawancara dengan Bapak Zainuddin Abbas (Kepala Bagian Pembiayaan Kantor Cabang Larangan), 28 Januari 2019.

Kodifikasia: Jurnal Penelitian Islam, Volume, 14 No. 1 Tahun 2020 
lancar, modal tidak kembali, dalam hal ini kami bisa mengkaji ulang apakah anggota masih bisa dipertahankan atau tidak. Jika anggota masih layak dipertahankan dan perlu adanya kelanjutan pada tambahan modal, akan dilakukan akad baru. Maka yang diharapkan adalah usaha dapat berkembang kembali dan mampu membayar kembali kewajibannya dengan baik.Apabila tidak ada harapan kembali, maka diperlukan adanya negoisasi untuk menjual assetnya yang menjadi barang jaminan menggantikan jumlah yang belum dibayar, dalam hal ini merupakan salah jalan terakhir yang bisa dilakukan dari pengendalian risiko pada pembiayaan." ${ }^{\prime 37}$

Dalam meminimalisir adanya manajemen risiko pembiayaan, salah satunya adalahdengan melakukan kerjasama baik antara kepala bagian legal dan remedial dengan Account Officer Pembiayaan (AOP). Risiko yang akan dihadapi dapat diketahui secara cepat dan dapat diberikan solusi apabila tim tersebut saling berkontribusi sesuai pada bidangnya dalam menangani pembiayaan, serta saling membantu dalam hal pembinaan dan pengawasan anggota pembiayaan. Seperti yang telah dijelaskan oleh pak Zainuddin Abbas:

"Dalam meminimalisir risiko yang akan dihadapi, maka proses manajemen risiko harus mampu dijalankan secara maksimal dan baik serta tepat. Dalam hal ini ada beberapa karyawan yang sangat penting dalam pembiayaan, saling membantu dan berkontribusi dalam proses efektif pemantauan. Sebelum pencairan dana pada anggota, karyawan bagian legal dan remedial mampu melakukan survey melalui Account Officer Simpanan dan Pembiayaan, melakuakn tugas penarikan simpanan serta angsuran pembiayaan. Dalam hal ini AOSP mengetahu lebih lanjut perkembangan usaha anggota setiap harinya dengan survey pada anggota langsung. Jika suatu saat usaha yang dilakukan melemah dan sering terlambat dalam angsuran, maka AOSP dapat memberitahukan kepada kepala legal dan remedial untuk melihat kondisi usaha tersebut. Setelah itu karyawan kepala bagian legal dan remedial bekerjasama dengan Account Officer Pembiayaan dalam menentukan cara yang efektif guna membina anggota tersebut. Jadi adanya kerja sama karyawan tim ini sangatlah berpengaruh pada strategi jalannya memaksimalkan manajemen risiko yang akan dihadapi dan telah dijalankan sesuai rencana." ${ }^{38}$

Berikut ini, merupakan bagan dari pengelolaan manajemen pembiayaan dalam proses pencairan dana kepada calon anggota.

${ }^{37}$ Wawancara dengan Bapak Zainuddin Abbas (Kepala Bagian Pembiayaan Kantor Cabang Larangan), 28 Januari 2019

${ }^{38}$ Wawancara dengan Bapak Zainuddin Abbas (Kepala Bagian Pembiayaan Kantor Cabang Larangan), 29 Januari 2019. 
Bagan 1

\section{Proses Pencairan Dana}

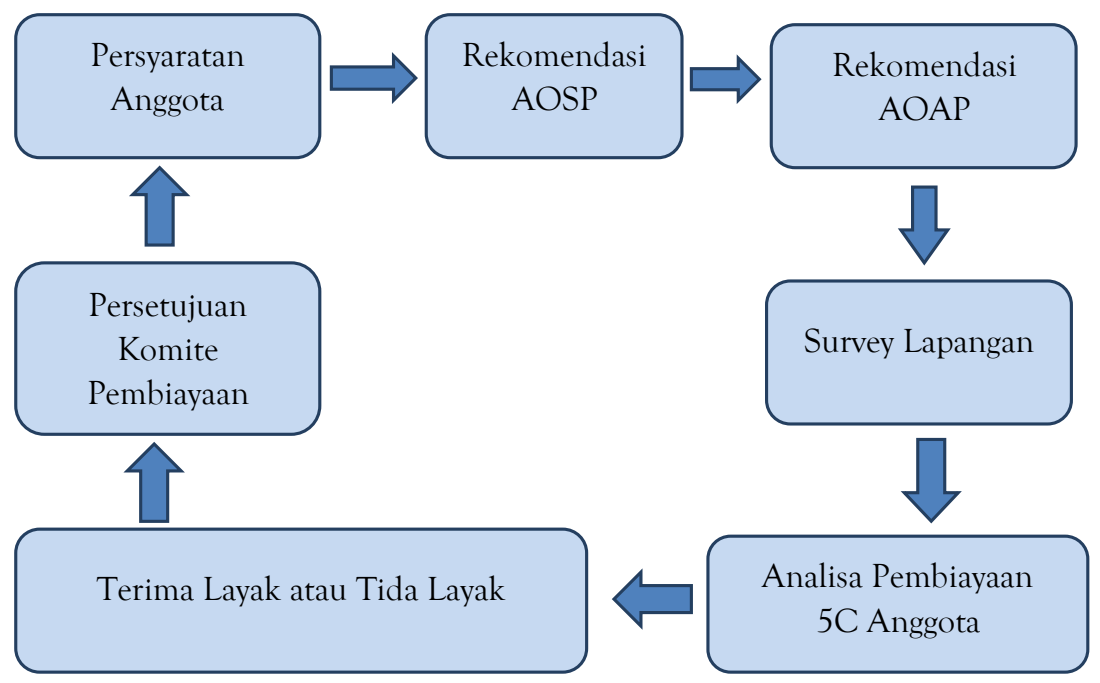

\section{Penerapan akad Syariah Dalam Manajemen Resiko Di BMT UGT Sidogiri}

Adapun bentuk penerapan kontrak bisnis syariah dalam manajemen resiko, BMT UGT Sidogiri menerapkan prinsip analisis pembiayaan 5C dan $1 \mathrm{~S}$ agar mampu menekankan adanya risiko pembiayaan dan memperoleh anggota yang lebih baik.Analisis Prinsip tersebut terdiri dari: ${ }^{39}$

a. Character $^{40}$

Karakter adalah sifat dasar yang terbentuk dari proses waktu yang lama, sehingga telah menjadi kebiasaan dan terulang secara kontinudanmenjadi karakter. ${ }^{41}$ Penilaian karakter menjadi penilaian paling utama dalam analisis pembiayaan,.Demikian beberapa risiko yang dapat terjadi oleh calon anggota adalah sebagai berikut: ada anggota yang mampu namun tidak bersedia membayar, ada yang tidak mampu namunberssedia membayar, ada yang tidak mampu namun tidak beredia membayar, dan ada yang mampu namun tidak bersedia membayar.Dengan demikian BMT UGT Sidogiri melakukan panggilan oleh kepala cabang dengan

${ }^{39}$ Wawancara dengan Bapak Zainuddin Abbas (Kepala Bagian Pembiayaan Kantor Cabang Larangan), 26 Agustus 2018.

${ }^{40} \mathrm{Ibid}$

${ }^{41}$ Karakter memiliki kesamaan arti dengan moral.Moral merupakan kondisi pikiran, perasaan, ucapan, dan perilaku manusia yang terkait dengan nilai-nilai baik dan buruk. Lihat, Samrin, "Pendidikan Karakter (Sebuah Pendekatan Nilai)," Jurnal Al-Ta'dib 9(1) (2016): 123 .

Kodifikasia: Jurnal Penelitian Islam, Volume, 14 No. 1 Tahun 2020 
kekeluargaan.Maka sangat ditekankan untuk selektif kepada calon anggota

Penilaianterhadap karakter pemohon pembiayaan adalah dengan adanya ketentuan dan syarat dari pihak BMT UGT Sidogiri yaknipemberian formulir kepada pemohon pembiayaan sebagai data awal calon penerima pembiayaan debitur.Dengan kuesioner survey maka pihak BMT dapat mengumpulkan informasi tentang karakter calon anggota.Dalam hal ini dibutuhkan adanya prinsip pendekatan BMT dalam menganalisis karakter anggota yang mengajukan produk pembiayaan. Untuk itu pihak BMT UGT Sidogiri melakukan tindakan sebagai berikut:

1. Verifikasi data, dilakukan dengan cara mempelajari riwayat hidup calon anggota selama menjadi anggota di BMT UGT Sidogiri.

2. Melakukan wawancara dengan calon anggota untuk mengetahui bagaimana karakter dari calon anggota tersebut.

b. Capacity

Capacity merupakan analisis yang dapat digunakan untuk mengetahui kemampuan keuangan nasabah dalam memenuhi kewajiban sesuai dengan jangka waktu yang ditentukan. ${ }^{42}$ Berikut adalah beberapa pendekatan untuk mengetahui kemampuan berusaha: pendekatan kauangan (liquiditas, solvabilitas dan retabilitas), pendekatan edukasi (latar belakang pendidikan dan keahlian), pendekatan manjerial (kemampuan melakukan fungsi manajemen: produksi, pemasaran dan keuangan), pendekatan teknikal (kemampuan mengelola faktor produksi, administrasi dan keuangan, hubungan industri dan sebagainya).${ }^{43}$ Demikian adalah upaya BMT UGT Sidogiri dalam menentukan kapasitas anggota.Kapasitas anggota sebagai acuan untuk mengetahui kemampuan anggota dalam bekerja dan memenuhi kewajiban setor angsuran.Risiko yang terjadi berkaitan dengan kemampuan calon anggota berdasarkan jangka waktu yang diterapkan.

Adanya kemampuan calon anggota pembiayaan dapat dilihat dari kemampuan memimpin suatu usaha dengan baik dan benar. Apabila kemampuan memimpin serta mengetahui pembukuan keuangan usahanya baik, maka dapat dipastikan pembayaran pembiayaan pinjamanpun akan berjalan dengan baik.

c. Capital

${ }^{42}$ Amirudin K, "Kelayakan Nasabah Dalam Pemberian Pembiayaan Kredit Kepemilikan Rumah Pada Kantor Bank Pembiayaan Rakyat Syariah Investama Mega Bakti Makassar," Al-Mashrafiyah: Jurnal Ekonomi, Keuanganan dan Perbankan Syariah 2(2) (2018): 65.

${ }^{43}$ Wawancara dengan Bapak Zainuddin Abbas (Kepala Bagian Pembiayaan Kantor Cabang Larangan), 26 Agustus 2018. 
Capitalmerupakankomposisibesarmodalyangdikeluarkandaridirisendiri dibandingkan dengan modal pinjaman dana untuk perusahaan. ${ }^{44}$ Dengan ini maka dapat diketahui banyak modal yang dimiliki oleh calon anggota pembiayaan, sehingga tidak seluruhnya bergantung modal pinjaman dari BMT.Dalam hal ini penting bagi BMT untuk mengetahui pendapatan yang dimiliki oleh calon anggota pembiayaan. Besar pendapatan calon anggota tentu berpengaruh terhadap kelancaran pembayaranangsuran yang telah disepakati.

Kemampuan calon anggota pembiayaan pihak BMT UGT Sidogiri dapat diketahui dengan melakukan beberapa analisis yaitu: ${ }^{45}$

1. Melihat laporan keuangan dan omset usaha calon anggota untuk tiap bulannya.

2. Menganalisa laporan keuangan usaha calon anggota pembiayaan dengan melakukan wawancara dan kunjungan langsung ke tempat calon anggota pembiayaan.

3. Wawancara masyarakat sekitar tentang usaha yang dijalankan oleh calon anggota dan mengetahui berapa laba bersih usaha dibandingkan dengan modal.

\section{d. Collateral ${ }^{46}$}

Secara umum pembiayaan bisa mendapat persetujuan oleh bank apabila nasabah menyertakan permohonan dengan jaminan (collateral) yang layak. ${ }^{47}$ Jaminan harus dinilai dan diprediksi dengan adanya, collateral valuation (ketetapan nilai jaminan), liquidity (proses likuidasi cepat atau lambat), depreciability (penyusutan atau kadar jaminan), marketability (pasar atau kemudahan dalam menjual), contrability (pengawasan jaminan tempat/lokasi). Menurut BMT UGT Sidogiri, dengan kondisi ekonomi yang baik anggota dapat melakukan pembiayaan murabahah bil wakalah dalam pembelian yang diinginkan sedang jaminan dinomorduakan. Dalam arti, apabila anggota baru pertama kaliakan melakukan pembelian pembiayaan, maka jaminan berupa BPKB

${ }^{44}$ Capital ini menjadi penting untuk mengetahui sumber-sumber pembiayaan yang dimiliki nasabah terhadap usaha yang akan dibiayai. Lihat, Saduldyn Pato, "Analisis Pemberian Kredit Mikro Pada Bank Syariah Mandiri Cabang Manado," Jurnal EMBA 1(4) (2013): 877.

${ }^{45}$ Wawancara dengan Bapak Zainuddin Abbas (Kepala Bagian Pembiayaan Kantor Cabang Larangan), 26 Agustus 2018.

${ }^{46}$ Wawancara dengan Bapak Zainuddin Abbas (Kepala Bagian Pembiayaan Kantor Cabang Larangan), 26 Agustus 2018.

${ }^{47}$ Muhammad Maulana, "Jaminan Dalam Pembiayaan Pada Perbankan Syariah Di Indonesia (Analisis Jaminan Pembiayaan Musyarakah Dan Mudarabah)," Jurnal Ilmiah Islam Futura 14(1) (2014): 73.

Kodifikasia: Jurnal Penelitian Islam, Volume, 14 No. 1 Tahun 2020 
kendaraan dan nilai pemberian dapat setengah dari nilai jaminan yang diberikan.

Namun jaminan tidak lagi diperlukan apabila anggota sudah lebih dari sekali melakukan pembiayaan.Jaminan diberikan oleh anggota kepada BMT UGT Sidogiri sebagai suatu kepercayaan dalam pemberian pembiayaan, sehingga risiko dapat dikurangi.Nilai suatu jaminan dapat melebihi jumlah pembiayaan yang diberikan, yangakan dipergunakan dan dilakukan sesuai pada perjanjian yang telah disepakati.

e. Condition of Economic

Perusahaan sangat dipengaruhi oleh Lingkungan eksternal terutama bagi dia yang memiliki skala pasar luas dengan teknologi tinggi. ${ }^{48}$ Penilaian terhadap pembiayaan oleh BMT UGT Sidogiri hendaknya dimulai dalam kondisi ekonomi sekarang.Maka sebaiknya pembiayaan diberikan dengan melihat prospek usaha tersebut dimasa akan datang.

Faktor diatas tentu berpengaruh terhadap angsuran pembiayaan calon anggota, seperti keadaan ekonomi yang berpengaruh terhadap kredit macet anggota, misalnya: jumlah barang yang sudah dimiliki, pekerjaan sampingan selain menjual sandal, jumlah tanggungan keluarga dan lainnya.Maka analisis survey dan investigasi sangat diperluan sebelum pembiayaan dicairkan untuk mengantisipasi kemungkinan adanya kredit macet disebabkan kondisi.

f. Syariah ${ }^{49}$

Syariah yang dimaksud dalam analisis pembiayaan berkaitan dengan produk yang dihasilkan anggota harus produk yang halal, tidak diperkenankan memberikan pembiayaan kepada anggota yang mengoperasikan dengan cara yang tidak halal. Hal ini dapat dilakukan BMT UGT Sidogiri dengan melihat bidang usaha anggota pembiayaan dan mengkaji kebutuhan pembiayaan agar tidak bertentangan prinsip syariah.

Dalam menjalankan aktifitasnya, Kepala Cabang BMT UGT Sidogiri saat ini lebih memilih untuk melakukan upaya meminimalisir risiko pembiayaan dengan cara non ligitasi atau keterpaksaan kepada anggota, karena dapat ditinjau dari anggota-anggota BMT UGT Sidogiri merupakan

${ }^{48}$ Lingkungan eksternal meliputi lingkungan makro dan mikro yang terdiri dari demografi, politik, teknologi, ekonomi, sosial budaya, supplier, konsumen, pesaing, distributor, institusi pemerintah, tenaga kerja, dan kreditor. Lihat, Novita Wahyu Setyowati, "Pengaruh Lingkungan Eksternal Dan Lingkungan Internal Terhadap Keunggulan Bersaing Pada Industri Kecil Dan Menengah Di Bandung, Jawa Barat," Jurnal Bisnis dan Manajemen 5(1) (2015): 13-14.

${ }^{49}$ Wawancara dengan Bapak Zainuddin Abbas (Kepala Bagian Pembiayaan Kantor Cabang Larangan), 26 Agustus 2018. 
masyarakat dengan kondisi perekonimian menengah kebawah. Sifat adanya BMT UGT Siogiri mampu membangun kekeluargaan dan amanah, tidak hanya bertujuan untuk memperoleh keuntungan yang diharapkan dalam menjalankan usahanya, tetapi bertujuan untuk mensyiarkan dakwah tentang agama Islam kepada masyarakat muamalah yang baik dalam umat muslim, memberikan bantuan saling menolong antar pihak BMT dan masyarakat sekitar BMT, anggota dalam usaha pasar dan anggot BMT UGT Sidogiri khususnya.

\section{PENUTUP}

\section{Kesimpulan}

Dalam pengelolaannya, manajemen risiko sangat berkaitan dengan operasional lembaga keuangan. BMT UGT Sidogiri telah menerapkan manajemen risikoterhadap berbagai kegiatan penyaluran dana pembiayaan. Manajemen risiko di BMT UGT Sidogirimenggunakan analisis prinsip $5 \mathrm{C}+1 \mathrm{~S}$ yang terdiri dari Character, Capital, Collateral, Condition of Economics dan Shariah. Dalam prakteknya pihak BMT telah sesuai dengan SOP (Standar Operasional Prosedur), maka dapat meminimalisir risiko yang akan dihadapi dengan baik. Selain itu secara tidak langsung juga dapat meningkatkan penyaluran dana pada kebutuhan masyarakat sebagai anggota.

Diantara keunggulan manajemen risiko BMT UGT Sidogiri dalam penanggulangan terhadap pembiayaan kurang lancar adalah menjalin komunikasi baik dalam dakwah dan kekeluargaan terhadap debitur bermasalah. BMT melakukan kunjungan atau penagihan kerumah anggota bermasalah.BMT memberikan penjelasan dan arahan terkait dengan perjanjian pembiayaan kepada debitur (anggota).Adanya pengamalan ibadah juga dilakukan yakni dengan melakukan istighotsah meminta pertolongan ketika keadaan sukar dan sulit.Dengan ini BMT UGT Sidogiri selalu menjaga hubungan baik dengan debitur (anggota).

\section{SARAN}

Pada pembiayaan murabahah dan musyarakah masih dibutuhkan untuk pengembangan skill pada aspek pemasaran produk pembiayaan.Dengan adanya pengembangan skill ini maka diharapkan dapat meningkatkan jumlah anggota dalam pembiayaan kemitraan.Mampu mempertahankan anggota dalam simpanan dan pembiayaan kepada BMT UGT Sidogiri. Dampak positif tentu dapat dirasakan oleh masyarakat pedesaan dengan meningkatnya jumlah anggota. Sebab, di samping mereka dapat belajar 
Model Penerapan Kontrak Bisnis Syariah ｜ 191

bisnis dengan baik dan benar, pengetahuan perihal ekonomi syariah pun akan dipahami. 


\section{DAFTAR RUJUKAN}

Abbas Arfan, Saifullah, dan Fakhruddin. "Implementasi Prinsip Bagi Hasil dan Manajemen Risiko dalam Produk-Produk Pembiayaan Perbankan Syariah di Kota Malang." INFERENSI, Jumal Penelitian Sosial Keagamaan 10(1) (2016).

Asmirawati, dan Sumarlin. "Perilaku Moral Hazard Nasabah Pada Pembiayaan Berbasis Bagi Hasil Pada Perbankan Syariah." Jurnal Laa Maysir 5(1) (2018).

Batlajery, Samuel. "Penerapan Fungsi-Fungsi Manajemen Pada Aparatur Pemerintahan Kampung Tambat Kabupaten Merauke." Jurnal Ilmu Ekonomi E Sosial 7(2) (2016).

Bustami. "Manajemen Risiko Pembiayaan Dardhul Hasan Menurut Perspektif Ekonomi Islam (Studi pada Baitul Qiradh Amanah Banda Aceh)." Jurnal Share 3(1) (2014).

Chaudry, Muhammad Sharif. Sistem Ekonomi Islam: Prinsip Dasar. Diterjemahkan oleh Suherman Rosyidi. Jakarta: Kencana Prenada Media Group, 2012.

Hajar. "The Financing Risk Management Analysis of Natural Uncertainty Contracts (NUC): Study of PT. Bank Syariah Mandiri Area Office of Malang." Journal 'Anil Islam 10(1) (2017).

Juried. "Manajemen Risiko Bank Islam (Penanganan Pembiayaan Bermasalah Dalam Produk Pembiayaan Pada PT. Bank Muamalat Cabang Pembantu Penyambungan)." Journal Analytica Islamica 5(1) (2012).

K, Amirudin. "Kelayakan Nasabah Dalam Pemberian Pembiayaan Kredit

Kepemilikan Rumah Pada Kantor Bank Pembiayaan Rakyat Syariah Investama Mega Bakti Makassar.” Al-Mashrafiyah: Jurnal Ekonomi, Keuanganan dan Perbankan Syariah 2(2) (2018).

Karim, Adiwarman A. Bank Islam: Analisis Fiqih dan Keuangan. Jakarta: Raja Grafindo Pustaka, 2014.

Kurnia, Riana Afliha Eka. "Manajemen Risiko Pembiayaan Untuk Mengantisipasi Kondisi Financial Distress Pada Bank Syariah." Journal of Islamic Economic Lariba 3(2) (2017).

Kodifikasia: Jurnal Penelitian Islam, Volume, 14 No. 1 Tahun 2020 
Maulana, Muhammad. "Jaminan Dalam Pembiayaan Pada Perbankan Syariah Di Indonesia (Analisis Jaminan Pembiayaan Musyarakah Dan Mudarabah)." Jurnal Ilmiah Islam Futura 14(1) (2014).

Mukhlisin, Ahmad, dan Aan Suhendri. "Analisis Manajemen Risiko (Kajian Kritis Terhadap Perbankan Syariah di Era Kontemporer).” An-Nisbah: Jurnal Ekonomi Syariah 5(1) (2018).

Nisrina, Riska, Fathur Rahman, dan Dkk. "Pengukuran Risiko Pembiayaan Pada BMT Di Kota Tasikmalaya." Jurnal Riset Akuntansi dan Keuangan 6(3) (2018).

Nurhayati, Erni. "Pelaksanaan Pengawasan Murabahah Sebagai Upaya Untuk Memimalkan Pembiayaan Bermasalah.” UIN Malang, 2010.

Pariyanti, Eka. "Analisis Pengendalian Resiko Pada Usaha Keripik Singkong." Jurnal Manajemen Magister 3(1) (2017).

Pato, Saduldyn. "Analisis Pemberian Kredit Mikro Pada Bank Syariah Mandiri Cabang Manado." Jurnal EMBA 1(4) (2013).

Samrin. "Pendidikan Karakter (Sebuah Pendekatan Nilai)." Jurnal Al-Ta'dib 9(1) (2016).

Setyowati, Novita Wahyu. "Pengaruh Lingkungan Eksternal Dan Lingkungan Internal Terhadap Keunggulan Bersaing Pada Industri Kecil Dan Menengah Di Bandung, Jawa Barat." Jurnal Bisnis dan Manajemen 5(1) (2015).

Sugana, Asep Dadan. "Mengurangi Tingkat Risiko Dengan Manajemen Islami.” Islamiconomic Jurnal Ekonomi Islam 6(2) (2015).

Sulistyaningsih, dan Barbara Gunawan. "Analisis Faktor-Faktor yang memengaruhi Risk Management Disclosure (Studi Empiris Pada Perusahaan Manufaktur yang Terdaftar di Bursa Efek Indonesia Tahun 2012-2014)." Analisis Faktor-Faktor yang memengaruhi Risk Management Disclosure (Studi Empiris Pada Perusahaan Manufaktur yang Terdaftar di Bursa Efek Indonesia Tahun 2012-2014), 2016.

Sumar'in. Konsep Kelembagaan Bank Syariah. Yogyakarta: Graha Ilmu, n.d.

Syamsuir. "LembagaKeuangan Islam Non Bank." Jurnal Islamika 15(1) (2015).

Wibowo, Endro. "Manajemen Risiko Pembiayaan Murbahah di BMT Amanah Ummah." Jurnal Al-Tijarah 1(2) (2015). 
194 I Mohammad Ghozali, Abdul Hafidz bin Zaid, Badria Nur Lailina Ulfa

Wijayantini, Bayu. "Model Pendekatan Manajemen Risiko." Jurnal Jeam 11(2) (2012).

Yasa, I W. Wedana, dan Dkk. "Manajemen Risiko Operasional Dan Pemeliharaan Tempat Pembuanagan Akhir (TPA Regional Bangli Di Kabupaten Bangli." Jurnal Spektran 1(2) (2013).

Yudiana, Fetria Eka. "Manajemen Risiko dalam Prinsip Pembiayaan Mudharabah: Kajian Kontekstual Islam terhadap Risiko." Jurnal Muqtashid 1(2) (2010).

Dokumen BMT UGT Sidogiri Standar Operasional dan Prosedur Tahun 2017

Dokumen Buku Panduan Rapat Anggota Tahunan KSPS BMT UGT Sidogiri Indonesia Tahun Buku 2017

Sejarah Berdirinya BMT UGT Sidogiri Pasuruan Jawa Timur (online) di https://www.bmtugtsidogiri.co.id/tentang-kami-6.html.28 Februari 2018 